\title{
Digital Literacy: Teachers' Perceptions of Using Google Accounts in the Online Learning Process
}

\author{
Fatmawati $^{1}$, Noni Andriyani ${ }^{2}$, Rika Ningsih ${ }^{3}$
}

DOI: 10.35445/alishlah.v13i2.596

\begin{tabular}{|c|c|}
\hline Article Info & Abstract \\
\hline $\begin{array}{l}\text { Keywords: } \\
\text { Digital Literacy; } \\
\text { Google Classroom; } \\
\text { Google Meet; } \\
\text { Google Formulir; } \\
\text { Learning Process }\end{array}$ & $\begin{array}{l}\text { This current study explores the teacher's perspective on the usefulness of google } \\
\text { account in the online learning process at SMAN } 1 \text { Tambang, Riau. The teachers } \\
\text { and other school staff did not simply implement the policy of the distance } \\
\text { learning process. The shift from face-to-face learning activities to online } \\
\text { learning is confusing for teachers, especially senior teachers. Teachers are } \\
\text { challenged to be able to use technology in carrying out their duties. The digital } \\
\text { literacy of teachers is critical in the implementation of online learning. Hence, } \\
\text { an understanding of google classroom, google meet, and google form is an } \\
\text { influential media aid in the learning process, especially in online learning. The } \\
\text { research method used is a survey method. The sample in this study was } 46 \\
\text { teachers of SMAN } 1 \text { Tambang. The results showed that } 46 \text { respondents who } \\
\text { filled out the research questionnaire, } 75 \% \text { stated Strongly Agree, } 23 \% \text { stated } \\
\text { Agree, and } 2 \% \text { stated Disagree that google accounts were instrumental in the } \\
\text { process of online learning during the Covid-19 pandemic. This result shows that } \\
\text { the Google account is an effective learning media used in the online learning } \\
\text { process during the Covid-19 pandemic. Therefore, teacher mastery in the use of } \\
\text { Google accounts is part of digital literacy that needs improvement. }\end{array}$ \\
\hline
\end{tabular}

\begin{abstract}
Abstrak
Penelitian ini bertujuan untuk mengeksplorasi perspektif guru terhadap kebermanfaatan akun google dalam proses pembelajaran daring di SMAN 1 Tambang, Riau. Kebijakan untuk melaksanakan proses pembelajaran jarak jauh ternyata tidak begitu saja bisa dilaksanakan oleh guru dan perangkat sekolah lainnya. Peralihan aktivitas pembelajaran lansung ke pembelajaran daring juga cukup membingungkan bagi guru, terutama bagi guru-guru senior. Guru ditantang untuk mampu menggunakan teknologi dalam menjalankan tugas-tugasnya. Literasi digital para guru menjadi hal yang sangat penting dalam pelaksanaan pembelajaran daring. Oleh karena itu, pemahaman tentang google classroom, google meet, dan google formulir merupakan media bantu yang efektif dalam proses pembelajaran khususnya pada pembelajaran daring. Metode penelitian yang digunakan adalah metode survei. Sampel dalam penelitian ini adalah 46 orang guru SMAN 1 Tambang. Hasil penelitian menunjukkan bahwa dari 46 orang responden yang mengisi angket penelitian, terdapat $75 \%$ yang menyatakan Sangat Setuju, 23\% menyatakan Setuju, dan 2\% menyatakan Tidak Setuju bahwa akun google (google classroom, google meet, dan google formulir) sangat bermanfaat dalam proses pembelajaran daring pada
\end{abstract}

\footnotetext{
${ }^{1}$ Universitas Islam Riau, Pekanbaru, Riau

Email: fatmawati@edu.uir.ac.id

2 Universitas Islam Riau, Pekanbaru, Riau

Email: noniandriyani@edu.uir.ac.id

3 Universitas Islam Riau, Pekanbaru, Riau

Email: rikaningsih@edu.uir.ac.id
} 
masa pandemi Covid-19. Hal ini menunjukkan bahwa akun google merupakan media pembelajaran yang efektif digunakan dalam proses pembelajaran daring pada masa pandemi Covid-19. Oleh karena itu, penguasaan guru dalam pemanfaatan akun google merupakan bagian dari literasi digital yang perlu ditingkatkan.

\section{PENDAHULUAN}

Penyebaran virus Covid-19 yang sangat masif mengubah segala tatanan kehidupan manusia. Dunia pendidikan merupakan satu di antara sekian banyak aspek kehidupan yang mengalami dampak dari penyebaran virus Covid-19. Himbauan untuk tetap di rumah saja dan Pembatasan Sosial Berskala Besar memaksa semua orang untuk menghentikan aktivitas sehari-hari yang lazim dilaksanakan sebelum pandemi. Para orang tua semakin mencemaskan keselamatan anak-anaknya saat beraktivitas di luar rumah termasuk untuk tujuan belajar di sekolah. Sekolah-sekolah menghentikan kegiatan tatap muka demi mencegah penularan virus Covid-19.

Data penyebaran Covid-19 yang belum menunjukkan penurunan yang signifikan memang mencekam dan menjadi mengkhawatirkan. Namun, hidup harus terus berjalan. Kebutuhan anakanak akan ilmu pengetahuan tidak bisa dikesampingkan. Kondisi ini membuat para pelaku dunia pendidikan berjibaku dalam menentukan langkah terbaik dalam melaksanakan proses pembelajaran di masa pandemi Covid-19. Proses pembelajaran daring menjadi pilihan terbaik karena tidak harus mengumpulkan siswa di sekolah. Aydin \& Erol (2021) juga menyatakan hal yang senada bahwa model pendidikan jarak jauh digunakan sebagai model pembelajaran alternatif di masa pandemi Covid-19.

Kebijakan untuk melaksanakan proses pembelajaran jarak jauh ternyata tidak begitu saja bisa dilaksanakan oleh guru dan perangkat sekolah lainnya. Peralihan aktivitas pembelajaran lansung ke pembelajaran daring ternyata cukup membingungkan bagi guru, khususnya bagi guruguru senior. Guru ditantang untuk mampu menggunakan teknologi dalam menjalankan tugastugasnya. Literasi digital para guru menjadi hal yang sangat penting dalam pelaksanaan pembelajaran daring. Jauh sebelum pandemi Covid-19 melanda, Kementerian Pendidikan dan Kebudayaan (2017) telah menyatakan bahwa dalam upaya menyukseskan pembangunan Indonesia di abad ke-21, masyarakat Indonesia dituntut untuk menguasai enam literasi dasar. Keenam literasi dasar tersebut yaitu (1) literasi bahasa, (2) literasi numerasi, (3) literasi sains, (4) literasi digital, (5) literasi finansial, serta (6) literasi budaya dan kewargaan. Kemampuan literasi ini juga harus diimbangi dengan menumbuhkembangkan kompetensi yang meliputi kemampuan berpikir kritis/memecahkan masalah, kreativitas, komunikasi, dan kolaborasi. Namun, di masa pandemi Covid-19 ini, literasi digital menjadi hal yang sangat ditekankan untuk dikuasai.

Pentingnya lietarsi digital di masa pandemi, juga dikemukakan oleh Buchholz, dkk. Buchholz et al., (2020) menekankan bahwa Covid-19 telah mengharuskan warga dari segala usia menggunakan praktik literasi digital untuk belajar. Hal tersebut didukung oleh pendapat Nahdi dan Jatisunda (2020) yang menyatakan bahwa kemampuan literasi digital mutlak dibutuhkan dalam menerapkan strategi pembelajaran daring. Lebih lanjut beliau manambahkan bahwa mustahil menerapkan pembelajaran daring tanpa ditunjang literasi digital yang tinggi. Menurut Buckingham dalam (Kurnia dkk: 2019) literasi digital tidak hanya terkait dengan penguasaan teknis komputer melainkan juga pengetahuan serta emosi dalam menggunakan media dan perangkat digital.

Dalam penelitian yang dilakukan oleh Pradana (2017) dinyatakan bahwa google classroom sangat direkomandasikan untuk digunakan sebagai media dalam pelaksanaan pembelajaran, karena dapat digunakan siswa untuk belajar di luar waktu pelajaran. Memperkuat pernyataan di atas, Nirfayanti \& Nurbaeti (2019) menyatakan bahwa google classroom merupakan sebuah aplikasi yang memungkinkan terciptanya ruang kelas di dunia maya yang bisa menjadi sarana distribusi tugas, submit tugas bahkan menilai tugas-tugas yang dikumpulkan. Selanjutnya, Yasni (2020) juga menyatakan bahwa beragam media ajar digunakan seperti youtube, platform pendidikan seperti 
whatsapp, google classroom, google meet, zoom cloud meeting, the teacherscorner.net dapat menjadi alternatif solusi dalam pembelajaran, demi kelangsungan pembelajaran pada setiap satuan pendidikan. Hidayah, dkk (2020) juga menyatakan bahwa para guru memeroleh penambahan pengetahuan dalam mengoperasikan aplikasi google classroom dan google Formulir.

Berdasarkan pemaparan di atas, diperoleh gambaran bahwa google classroom, google meet, dan google formulir merupakan media bantu yang efektif dalam proses pembelajaran terkhusus pada pembelajaran daring. Oleh karena itu, peneliti memfokuskan literasi digital terkait pemanfaatan akun google yang terdiri dari google classroom, google meet, dan google formulir dalam proses pembelajaran daring. Berdasarkan latar belakang masalah yang telah dipaparkan di atas maka rumusan masalah dalam penelitian ini adalah bagaimana persepsi guru terhadap kebermanfaatan akun google dalam pembelajaran daring. Penelitian ini bertujuan untuk mengeksplorasi sejauh mana persepsi guru terhadap kebermanfaatan akun google dalam proses pembelajaran daring di SMAN 1 Tambang. Kebaharuan penelitian ini dibadingkan penelitian sebelumnya adalah, dalam penelitian ini difokuskan pada persepsi guru terhadap pemanfaatan akun google yang terdiri dari google classroom, google meet, dan google formulir dalam proses pembelajaran daring.

Penelitian ini menggunakan beberapa tinjauan pustaka. Berikut ini dipaparkan secara singkat beberapa teori yang digunakan dalam penelitian ini. Berdasarkan definisi yang disusun oleh Kementerian Pendidikan dan Kebudayaan (2017) literasi digital adalah pengetahuan dan kecakapan untuk menggunakan media digital, alat-alat komunikasi, atau jaringan dalam menemukan, mengevaluasi, menggunakan, membuat informasi, dan memanfaatkannya secara sehat, bijak, cerdas, cermat, tepat, dan patuh hukum dalam rangka membina komunikasi dan interaksi dalam kehidupan sehari-hari. Menurut Buckingham dalam (Kurnia dkk: 2019) literasi digital tidak hanya terkait dengan penguasaan teknis komputer melainkan juga pengetahuan serta emosi dalam menggunakan media dan perangkat digital. Selanjutnya, Acep, dkk (2018) menyatakan bahwa literasi digital adalah kemampuan menggunakan teknologi informasi dan komunikasi (TIK), untuk menemukan, mengevaluasi, memanfaatkan, membuat, dan mengkomunikasikan konten/informasi, dengan kecakapan kognitif maupun teknikal. Jika dikaitkan dengan kondisi pandemi, Saragih et al. (2021) menyatakan bahwa literasi digital menjadi satu-satunya pilihan di tengah wabah Covid-19 yang berdampak pada pendidikan di Indonesia.

Berdasarkan sejumlah definisi literasi digital di atas, dapat disimpulkan bahwa literasi digital berkenaan dengan kemampuan dalam menggunakan teknologi yang bisa dimanfaatkan dalam penyelesaian tugas-tugas sehari-hari. Salah satu contoh literasi digital adalah kecakapan dalam menggunakan akun google untuk keperluan penyelesaian tugas-tugas sehari-hari. Dalam kondisi pandemi seperti sekarang ini, aplikasi-aplikasi yang ditawarkan oleh google bisa dimanfaatkan terutama bagi guru dalam proses pembelajaran daring. Dalam penelitian ini, fokus pada persepsi guru terhadap pemanfaatan aplikasi google classroom, google meet, dan google formulir dalam proses pembelajaran daring.

\section{METODE}

Penelitian ini menggunakan pendekatan kuantitatif dengan metode penelitian survei. Metode survei dipilih karena dianggap sebagai metode yang paling relevan digunakan untuk menentukan bagaimana persepsi guru terhadap kebermanfaatan akun google dalam pembelajaran daring. Melalui metode penelitian survei diperoleh informasi yang komprehensif dari seluruh responden terkait dengan kebermanfaatan akun google dalam pembelajaran daring.

Penelitian ini dilaksanakan di SMAN 1 Tambang. SMAN 1 Tambang terletak di Jalan Pekanbaru-Bangkinang KM 29, Sungai Pinang, Kecamatan Tambang, Kabupaten Kampar, Riau. Sampel dalam penelitian ini diambil dengan menggunakan teknik sampling jenuh yang berarti semua populasi penelitian dijadikan sampel yang berjumlah 46 orang guru. Pelaksanaan penelitian dilakukan pada bulan Maret 2021. Prosedur penelitian dimulai dari menentukan masalah penelitian, 
menyusun instrumen survei dan menentukan sampel, Pengumpulan data, pengolahan data dan analisis data, serta menginterpretasikan dan menyimpulkan hasil penelitian. Berikut ini dipaparkan secara garis besar prosedur penelitian yang digunakan dalam penelitian ini.

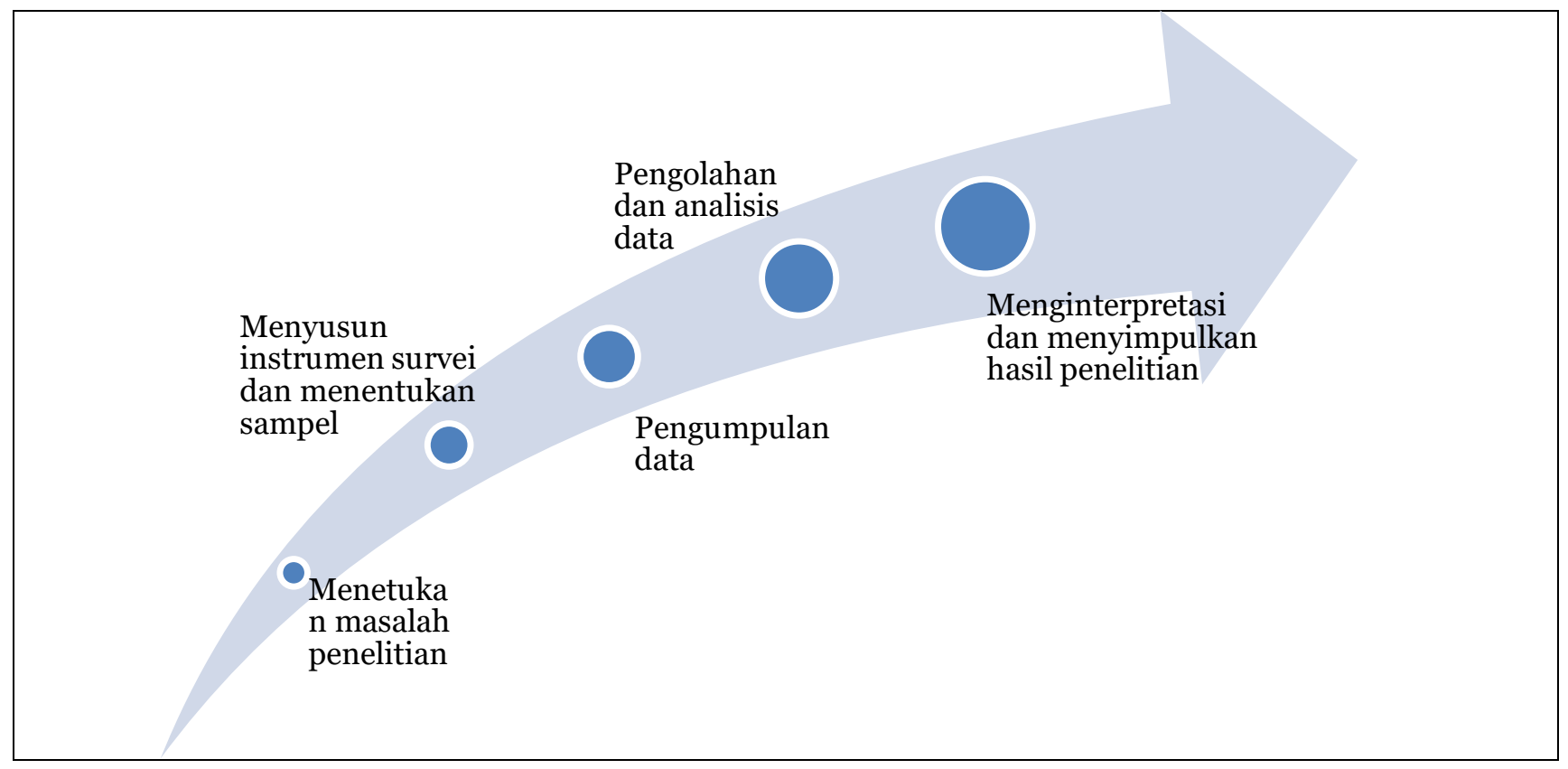

Gambar 1: Prosedur penelitian survei

Penelitian ini berawal dari pentingnya literasi digital bagi guru dalam menunjang tugastugasnya sebagai seorang pendidik. Literasi digital yang dimaksud adalah fokus pada pemanfaatan akun google yang terdiri dari aplikasi google classroom, google meet, dan google formulir dalam proses pembelajaran daring. Berdasarkan latar belakang yang peneliti jabarkan dibagian pendahuluan, dirumuskanlah masalah penelitian ini yakni bagaimana kebermanfaatan akun google dalam pembelajaran daring di SMAN 1 Tambang. Setelah ditentukan rumusan masalah penelitian ini, Langkah selanjutnya adalah penyusunan instrument penelitian. Instrumen penelitian ini terdiri dari 30 butir pernyatan dengan gradasi pilihan jawaban Sangat Setuju (SS) diberi bobot 4, Setuju (S) diberi bobot 3, Tidak Setuju (TS) diberi bobot 2, dan Sangat Tidak Setuju (STS) diberi bobot 1. Tahap selanjutnya adalah pengumpulan data. Pengumpulan data dalam penelitian ini dilakukan dengan cara menyebarkan angket yang sudah disusun melalui pranala google formulir. Hal tersebut dilakukan mengingat kondisi pandemi yang belum memungkinkan peneliti untuk bertemu secara langsung dengan semua guru di SMAN 1 Tambang. Selanjutnya, hasil isian angket melalui pranala google formulir tersebut dianalisis menggunakan statistik sederhana untuk mendapatkan informasi yang valid terkair kebermanfaatan akun google dalam pembelajaran daring. Langkat terakhir dari prosedur prosedur penelitian ini adalah menyimpulkan hasil penenlitian yang diperoleh dari data di lapangan.

\section{HASIL DAN PEMBAHASAN}

Berdasarkan data yang telah dikumpulkan melalui instrumen penenlitian, diperoleh sejumlah informasi dari 46 responden terkait pandangan mereka tentang literasi digital pada masa pandemi Covid-19 di SMAN khususnya pemanfaatan akun google dalam proses pembelajaran daring. Berikut ini dipaparkan hasil dari angket yang sudah diisi oleh 46 orang responden penelitian.

Sebelum mengajukan pertanyaan terkait kebermanfaatan akun google dalam proses pembelajaran daring, peneliti terlebih dahulu mengajukan pertanyaan terkait pernah tidaknya responden menggunakan akun google sebagai media pembelajaran. Hal tersebut dilakukan untuk mengetahui sejauh mana responden telah mengenal beberapa aplikasi yang disajikan oleh google. Berdasarkan pertanyaan yang diajukan, ternyata ada 15,2 \% responden yang sama sekali belum pernah 
menggunakan akun google sebagai media dalam pembelajaran daring. Hal tersebut menunjukkan bahwa literasi digital responden perlu ditingkatkan. Hal tersebut diperlukan untuk menambah pengetahuan literasi digital mereka serta membantu mereka dalam melaksanakan proses pembelajaran.

Setelah mendapatkan informasi mengenai persentasi responden yang sudah pernah menggunakan aplikasi google dalam proses pembelajaran, tahap berikutnya adalah pengolahan hasil survei kebermanfaatan akun google (google classroom, google meet, dan google formulir) dalam proses pembelajaran daring pada masa pandemi Covid-19. Untuk mengetahui hasil dari angket yang sudah diberikan, berikut ini disajikan hasil olahan angket dalam bentuk diagram.

Survei kebermanfaatan akun google (google classroom, google meet, dan google formulir) dalam proses pembelajaran daring pada masa pandemi Covid-19

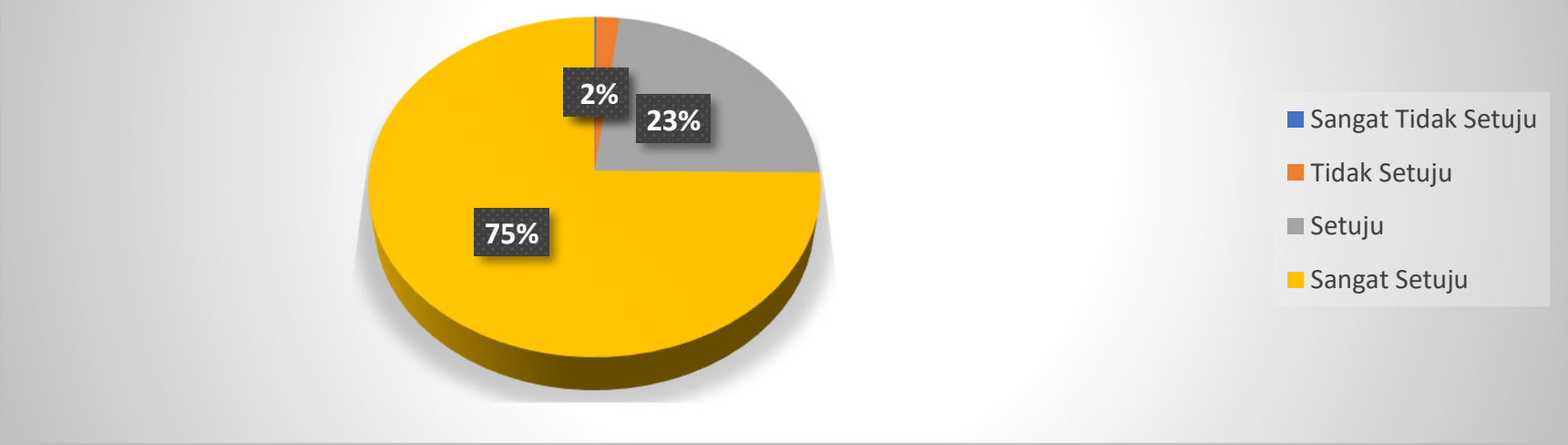

\section{Diagram 1 : Hasil survei kebermanfaatan akun google (google classroom, google meet, dan google formulir) dalam proses pembelajaran daring pada masa pandemi Covid-19}

Berdasarkan diagram di atas, diperoleh informasi bahwa dari 46 orang responden yang mengisi angket, terdapat $75 \%$ yang menyatakan Sangat Setuju bahwa akun google (google classroom, google meet, dan google formulir) sangat bermanfaat dalam proses pembelajaran daring pada masa pandemi Covid-19. Presentase responden yang menyatakan Setuju bahwa akun google (google classroom, google meet, dan google formulir) sangat bermanfaat dalam proses pembelajaran daring pada masa pandemi Covid-19 adalah 23\% dari 46 orang responden. Sementara itu, terdapat 2\% dari 46 orang responden yang menyatakan Tidak Setuju bahwa akun google (google classroom, google meet, dan google formulir) sangat bermanfaat dalam proses pembelajaran daring pada masa pandemi Covid-19. Dari 46 orang responden, tidak ada satu responden pun yang menyatakan Sangat Tidak Setuju bahwa akun google (google classroom, google meet, dan google formulir) bermanfaat dalam proses pembelajaran daring pada masa pandemi Covid-19. Hal ini menunjukkan bahwa akun google merupakan media pembelajaran yang efektif digunakan dalam proses pembelajaran daring pada masa pandemi Covid-19. Hasil penelitian ini sejalan dengan hasil penelitian yang dilakukan oleh Mu'minah \& Gaffar (2020) yang menyakan bahwa google classroom menjadi pilihan alternatif digitalisasi dalam pembelajaran jarak jauh karena dapat menghemat biaya, waktu dan lebih fleksibel. Selanjutnya, Suparjan \& Maryadi (2021) juga menyatakan hal yang sama bahwa google classroom menjadi salah satu pilihan sekolah dalam membantu pembelajaran online di masa pandemi Covid-19.

Untuk penyajian hasil penelitian secara lebih detail, pada kesempatan ini dipaparkan beberapa informasi yang diperoleh berdasarkan survei melalui angket. Pertama adalah respon terkait perlunya literasi digital pada masa pandemi Covid-19. Berdasarkan pernyataan butir 1, terdapat 41 orang responden atau 89,1\% yang menyatakan Sangat Setuju bahwa literasi digital dibutuhkan pada masa pandemi Covid-19. Sementara itu, terdapat 5 orang responden atau 10,9\% yang menyatakan Setuju bahwa literasi digital dibutuhkan pada masa pandemi. Dari 46 orang responden, tidak ada peserta yang menyatakan Tidak Setuju dan Sangat Tidak Setuju bahwa literasi digital dibutuhkan pada masa pandemi Covid-19. Hal ini menunjukkan bahwa secara keseluruhan, para guru SMAN 1 Tambang yang 
menjadi responden penenlitian ini menyadari bahwa literasi digital merupakan suatu keharusan dalam pelaksanaan pembelajaran pada masa pandemi Covid-19. Hal tersebut sejalan dengan pendapat Saragih et al. (2021) menyatakan bahwa literasi digital menjadi satu-satunya pilihan di tengah wabah Covid-19 yang berdampak pada pendidikan di Indonesia. Lebih rinci, Sumiati \& Wijonarko (2020) menyebutkan ada sepuluh manfaat literasi digital yang dapat dirasakan yaitu menghemat waktu, belajar lebih cepat, menghemat uang, membuat lebih aman, selalu memperoleh informasi terkini, selalu terhubung, membuat keputusan lebih baik, dapat membuat anda bekerja, membuat lebih bahagia, dan mempengaruhi dunia.

Kedua adalah respon terkait pernyataan bahwa penguasaan literasi digital membantu guru dalam pelaksanaan pembelajaran daring. Berdasarkan pernyataan butir 2, terdapat 39 orang responden atau $84,8 \%$ yang menyatakan Sangat Setuju bahwa penguasaan literasi digital membantu guru dalam pelaksanaan pembelajaran daring. Sementara itu, terdapat 5 orang responden atau 10,9\% yang menyatakan Setuju bahwa penguasaan literasi digital membantu guru dalam pelaksanaan pembelajaran daring. Untuk yang menyatakan Tidak Setuju dan Sangat Tidak Setuju bahwa penguasaan literasi digital membantu guru dalam pelaksanaan pembelajaran daring, masing-masing terdapat 1 orang atau masing-masing 2,2\%. Hal ini menunjukkan bahwa sebagian besar guru SMAN 1 Tambang mengakui bahwa penguasaan literasi digital membantu guru dalam pelaksanaan pembelajaran daring. Hal tersebut didukung oleh penelitian yang dilakukan oleh Saragih et al., (2021) yang menyatakan bahwa setiap sekolah harus memahami bahwa literasi digital adalah hal yang diperlukan dalam melakukan partisipasi pada dunia modern saat ini.

Ketiga adalah respon terkait pernyataan bahwa literasi digital guru hanya akan terasah jika guru memiliki keingginan untuk belajar. Berdasarkan pernyataan butir 3, terdapat 34 orang responden atau 73,9\% yang menyatakan Sangat Setuju bahwa literasi digital guru hanya akan terasah jika guru memiliki keingginan untuk belajar. Sementara itu, terdapat 10 orang responden atau 21,7\% yang menyatakan Setuju bahwa literasi digital guru hanya akan terasah jika guru memiliki keingginan untuk belajar. Untuk yang menyatakan Tidak Setuju bahwa literasi digital guru hanya akan terasah jika guru memiliki keingginan untuk belajar berjumlah 2 orang atau 4,3\%. Sementara itu, tidak ada satupun guru yang menyatakan Sangat Tidak Setuju bahwa literasi digital guru hanya akan terasah jika guru memiliki keingginan untuk belajar. Hal ini menunjukkan bahwa belajar adalah kunci kesuksesan. Seseorang tidak akan mampu menguasai teknologi jika tidak didukung oleh keingginan untuk selalu belajar. Oleh karena itu, tidak heran jika ada pepatah yang mengatakan bahwa belajar itu sepanjang hayat. Artinya, selama masih ada umur maka kita disarankan untuk selalu belajar untuk memperkaya pengetahuan dan pengalaman. Pentingnya peningkatan kompetensi guru juga disinggung oleh Sudrajat, (2020) yang menyatakan bahwa diperlukan pengembangan kompetensi penguasaan literasi dan IPTEK, kompetensi keterampilan pengelolaan kelas, serta kompetensi komunikasi dan sosial sehingga akan meminimalisasi masalah-masalah yang ada dalam pembelajaran daring, sehingga proses belajar dapat berjalan lebih baik.

Keempat adalah respon terkait pernyataan bahwa satu di antara literasi digital yang perlu dikuasai guru adalah pemanfaatan akun google melalui aplikasi google classroom, google meet, dan google formulir. Berdasarkan pernyataan butir 4, terdapat 34 orang responden atau 73,9\% yang menyatakan Sangat Setuju bahwa satu di antara literasi digital yang perlu dikuasai guru adalah pemanfaatan akun google melalui aplikasi google classroom, google meet, dan google formulir. Sementara itu, terdapat 11 orang responden atau $23,9 \%$ yang menyatakan Setuju bahwa satu di antara literasi digital yang perlu dikuasai guru adalah pemanfaatan akun google melalui aplikasi google classroom, google meet, dan google formulir. Untuk yang menyatakan Tidak Setuju bahwa satu di antara literasi digital yang perlu dikuasai guru adalah pemanfaatan akun google melalui aplikasi google classroom, google meet, dan google formulir berjumlah 1 orang atau 2,2\%. Sementara itu, tidak ada satupun guru yang menyatakan Sangat Tidak Setuju bahwa satu di antara literasi digital yang perlu dikuasai guru adalah pemanfaatan akun google melalui aplikasi google classroom, google 
meet, dan google formulir. Hal ini menunjukkan bahwa sebagian besar responden sepakat bahwa pemanfaatan akun google melalui aplikasi google classroom, google meet, dan google formulir merupakan bagian dari literasi digital yang perlu dikuasai. Hal tersebut sejalan dengan pendapat Mu'minah \& Gaffar (2020) yang menyatakan bahwa pengoptimalan fitur google classroom berdampak baik bagi pembelajaran saat ini, di antaranya adalah tidak terbatas oleh ruang dan waktu, materi pembelajaran yang dibutuhkan lebih mudah di akses, serta mampu melatih keterampilan literasi data dan literasi teknologi.

Kelima adalah respon terkait pernyataan bahwa pemanfaatan akun google melalui aplikasi google classroom, google meet, dan google formulir menjadi sarana yang efektif dalam mengantisipasi penyebaran Covid-19. Berdasarkan pernyataan butir 5, terdapat 35 orang responden atau 76,1,1\% yang menyatakan Sangat Setuju bahwa pemanfaatan akun google melalui aplikasi google classroom, google meet, dan google formulir menjadi sarana yang efektif dalam mengantisipasi penyebaran Covid-19. Sementara itu, terdapat 11 orang responden atau 23,9\% yang menyatakan Setuju bahwa pemanfaatan akun google melalui aplikasi google classroom, google meet, dan google formulir menjadi sarana yang efektif dalam mengantisipasi penyebaran Covid-19. Dari 46 orang responden, tidak ada peserta yang menyatakan Tidak Setuju dan Sangat Tidak Setuju bahwa pemanfaatan akun google melalui aplikasi google classroom, google meet, dan google formulir menjadi sarana yang efektif dalam mengantisipasi penyebaran Covid-19. Hal ini menunjukkan bahwa secara keseluruhan, para guru SMAN 1 Tambang yang menjadi responden penelitian ini menyadari bahwa melalui pemanfaatan akun google sekolah bisa menekan penyebaran Covid-19. Hal tersebut dikarenakan semua sarana dalam proses pembelajaran sudah disajikan oleh google melalui aplikasi-aplikasi yang ada. Hal tersebut didukung oleh pernyataan Mu'minah \& Gaffar (2020) yang menyatakan bahwa penggunaan google classroom sebagai alternatif digitalisasi dalam pembelajaran jarak jauh sebagai solusi dalam melaksanakan proses pembelajaran daring.

Keenam adalah respon terkait pernyataan bahwa proses pembelajaran tetap bisa berjalan dengan baik jika guru mampu memanfaatkan aplikasi google classroom, google meet, dan google formulir. Berdasarkan pernyataan butir 6 , terdapat 34 orang responden atau $73,9 \%$ yang menyatakan Sangat Setuju bahwa proses pembelajaran tetap bisa berjalan dengan baik jika guru mampu memanfaatkan aplikasi google classroom, google meet, dan google formulir. Sementara itu, terdapat 11 orang responden atau $23,9 \%$ yang menyatakan Setuju bahwa proses pembelajaran tetap bisa berjalan dengan baik jika guru mampu memanfaatkan aplikasi google classroom, google meet, dan google formulir. Untuk yang menyatakan Tidak Setuju bahwa proses pembelajaran tetap bisa berjalan dengan baik jika guru mampu memanfaatkan aplikasi google classroom, google meet, dan google formulir berjumlah 1 orang atau 2,2\%. Sementara itu, tidak ada satupun guru yang menyatakan Sangat Tidak Setuju bahwa proses pembelajaran tetap bisa berjalan dengan baik jika guru mampu memanfaatkan aplikasi google classroom, google meet, dan google formulir. Hal ini menunjukkan bahwa sebagian besar responden sepakat bahwa meskipun dalam masa pandemi Covid-19, proses pembelajaran tetap bisa berjalan dengan baik jika guru mampu memanfaatkan aplikasi google classroom, google meet, dan google formulir. Namun, tidak bisa dipungkiri bahwa masih banyak guru yang belum mahir dalam menggunakan aplikasi-aplikasi pembelajaran daring. Hal tersebut sejalan dengan hasil penelitian yang dilakukan oleh Asmuni (2020) bahwa pelaksanaan pembelajaran daring di masa pandemi Covid-19 memiliki beragam problematika yang dialami guru, berupa lemahnya penguasaaan IT.

Ketujuh adalah respon terkait pernyataan bahwa kondisi pandemi yang belum juga usai membuat guru harus kreatif dalam menggunakan media-media belajar agar siswa tetap bisa mendapatkan hak-haknya sebagai peserta didik. Berdasarkan pernyataan butir 27, terdapat 39 orang responden atau 84,8\% yang menyatakan Sangat Setuju bahwa kondisi pandemi yang belum juga usai membuat guru harus kreatif dalam menggunakan media-media belajar agar siswa tetap bisa mendapatkan hak-haknya sebagai peserta didik. Sementara itu, terdapat 6 orang responden atau 13\% yang menyatakan Setuju bahwa kondisi pandemi yang belum juga usai membuat guru harus kreatif 
dalam menggunakan media-media belajar agar siswa tetap bisa mendapatkan hak-haknya sebagai peserta didik. Untuk yang menyatakan Tidak Setuju bahwa kondisi pandemi yang belum juga usai membuat guru harus kreatif dalam menggunakan media-media belajar agar siswa tetap bisa mendapatkan hak-haknya sebagai peserta didik berjumlah 1 orang atau 2,2\%. Sementara itu, tidak ada satupun guru yang menyatakan Sangat Tidak Setuju bahwa kondisi pandemi yang belum juga usai membuat guru harus kreatif dalam menggunakan media-media belajar agar siswa tetap bisa mendapatkan hak-haknya sebagai peserta didik. Hal ini menunjukkan bahwa sebagian besar responden sepakat bahwa kondisi pandemi yang belum juga usai membuat guru harus kreatif dalam menggunakan media-media belajar agar siswa tetap bisa mendapatkan hak-haknya sebagai peserta didik. Terlait hal tersbeut, M. A. Wulandari et al., (2020) menyatakan bahwa dalam kondisi pandemi ini pembelajaran daring dapat dijadikan salah satu alternatif pembelajaran guna mencegah penularan Covid-19. Hal tersebut tentu didukung oleh kreatifitas guru dalam menggunakan aplikasi-aplikasi pembelajaran daring yang relevan.

Kedelapan adalah respon terkait pernyataan bahwa guru harus melek teknologi agar kebutuhan peserta didik tetap terpenuhi. Berdasarkan pernyataan butir 28, terdapat 41 orang responden atau $89,1 \%$ yang menyatakan Sangat Setuju bahwa guru harus melek teknologi agar kebutuhan peserta didik tetap terpenuhi. Sementara itu, terdapat 4 orang responden atau 8,7\% yang menyatakan Setuju bahwa guru harus melek teknologi agar kebutuhan peserta didik tetap terpenuhi. Untuk yang menyatakan Tidak Setuju bahwa guru harus melek teknologi agar kebutuhan peserta didik tetap terpenuhi berjumlah 1 orang atau 2,2\%. Sementara itu, tidak ada satupun guru yang menyatakan Sangat Tidak Setuju bahwa guru harus melek teknologi agar kebutuhan peserta didik tetap terpenuhi. Hal ini menunjukkan bahwa sebagian besar responden sepakat bahwa guru harus melek teknologi agar kebutuhan peserta didik tetap terpenuhi. Hal tersebut sejalan dengan pernyataan Ibda (2018) bahwa Guru harus paham dan menguasai literasi abad 21 yang menekankan pengetahuan berbasis data, teknologi, dan humanisme, bukan sekadar kemampuan membaca, menulis dan berhitung saja.

Kesembilan adalah respon terkait pernyataan bahwa kondisi pandemi saat ini semakin membuktikan bahwa literasi digital merupakan hal yang sangat penting bagi guru. Berdasarkan pernyataan butir 29, terdapat 39 orang responden atau 84,8\% yang menyatakan Sangat Setuju bahwa kondisi pandemi saat ini semakin membuktikan bahwa literasi digital merupakan hal yang sangat penting bagi guru. Sementara itu, terdapat 7 orang responden atau 15,2\% yang menyatakan Setuju bahwa kondisi pandemi saat ini semakin membuktikan bahwa literasi digital merupakan hal yang sangat penting bagi guru. Dari 46 orang responden, tidak ada peserta yang menyatakan Tidak Setuju dan Sangat Tidak Setuju bahwa literasi digital merupakan hal yang sangat penting bagi guru. Hal ini menunjukkan bahwa secara keseluruhan, para guru SMAN 1 Tambang yang menjadi responden dalam penelitian ini menyadari bahwa literasi digital merupakan hal yang sangat penting bagi guru. Hal tersebut sejalan dengan pendapat Indrianto et al., (2021) yang menyatakan bahwa pandemi justru menjadi momen yang tepat untuk mempercepat digitalisasi sekolah. Saat ini, digitalisasi sekolah merupakan suatu kebutuhan dan keharusan sebagai solusi terhadap tantangan dan perkembangan zaman. Dengan demikian, penggunaan teknologi adalah keniscayaan yang tidak dapat dihindari di masa saat ini. Pernyataan tersebut juga sejalan dengan pernyataan Sutrisna, (2020) bahwa pada masa pandemi Covid-19, setiap individu perlu memahami bahwa literasi digital merupakan hal penting yang dibutuhkan untuk dapat berpartisipasi di dunia modern dan mengantisipasi penyebaran informasi negartif pada masa pandemi Covid-19. Literasi digital akan menciptakan tatanan masyarakat dengan pola pikir dan pandangan yang kritis-kreatif.

Kesepuluh adalah respon terkait pernyataan bahwa proses pembelajaran daring hanya akan berhasil jika semua eleman sekolah saling bersinergi. Berdasarkan pernyataan butir 30, terdapat 41 orang responden atau 89,1\% yang menyatakan Sangat Setuju bahwa proses pembelajaran daring hanya akan berhasil jika semua eleman sekolah saling bersinergi. Sementara itu, terdapat 3 orang 
responden atau 6,5\% yang menyatakan Setuju bahwa proses pembelajaran daring hanya akan berhasil jika semua eleman sekolah saling bersinergi. Untuk yang menyatakan Tidak Setuju bahwa proses pembelajaran daring hanya akan berhasil jika semua eleman sekolah saling bersinergi berjumlah 2 orang atau 4,3\%. Sementara itu, tidak ada satupun guru yang menyatakan Sangat Tidak Setuju bahwa proses pembelajaran daring hanya akan berhasil jika semua eleman sekolah saling bersinergi. Hal ini menunjukkan bahwa sebagian besar responden sepakat bahwa proses pembelajaran daring hanya akan berhasil jika semua eleman sekolah saling bersinergi.

Berdasarkan pemaparan di atas, sudah sepantasnyalah para guru untuk memahami fitur-fitur yang disajikan dalam akun google. Hasil penelitian ini sejalan dengan hasil penelitian Ashadii \& Suhaeb (2020) yang menyatakan bahwa pemanfaatan media pembelajaran berbasis online dapat memengaruhi hasil belajar, sehingga tenaga pendidik harus cermat dalam memilih dan menggukan media. Lebih lanjut, I. A. G. Wulandari, (2021) menyatakan bahwa penggunaan media google classroom dalam masa belajar di rumah, hendaknya dikombinasikan dengan aplikasi lainnya yang mendukung, seperti penggunaan video call sehingga pendidik dapat berinteraksi dengan peserta didik. Hal tersebut memudahkan peserta didik dalam memahami materi yang disajikan. Penggunaan video call bisa dilakukan melalui pemanfaatan aplikasi google meet. Namun, kita harus menyadari bahwa meskipun sudah dilakukan sejumlah upaya untuk memaksimalkan pembelajaran daring, keterbatasan guru dan siswa dalam pelaksanaan kegiatan pembelajaran di tengah wabah pandemi Covid-19 akan tetap ada (Lynch, 2020). Tugas kita adalah berusaha untuk memaksimalkan semua potensi yang ada untuk mewujudkan pendidikan yang berkualitas di tengah wabah pandemi Covid-19.

\section{SIMPULAN}

Setelah melakukan serangkaian prosedur penenlitian, diperoleh beberapa kesimpulan sebagai berikut. Pertama, diperoleh informasi bahwa dari 46 orang responden yang mengisi angket penelitian, terdapat $75 \%$ yang menyatakan Sangat Setuju bahwa akun google (google classroom, google meet, dan google formulir) sangat bermanfaat dalam proses pembelajaran daring pada masa pandemi Covid-19. Presentase responden yang menyatakan Setuju bahwa akun google (google classroom, google meet, dan google formulir) sangat bermanfaat dalam proses pembelajaran daring pada masa pandemi Covid-19 adalah 23\% dari 46 orang responden. Sementara itu, terdapat 2\% dari 46 orang responden yang menyatakan Tidak Setuju bahwa akun google (google classroom, google meet, dan google formulir) sangat bermanfaat dalam proses pembelajaran daring pada masa pandemi Covid-19. Hal ini menunjukkan bahwa akun google merupakan media pembelajaran yang efektif digunakan dalam proses pembelajaran daring pada masa pandemi Covid-19. Oleh karena itu, penguasaan guru dalam pemanfaatan akun google merupakan bagian dari literasi digital yang perlu ditingkatkan.

\section{DAFTAR PUSTAKA}

Acep, S., \& dkk. (2018). Kerangka Literasi Digital. Kominfo Publisher. https://ejournal.poltektegal.ac.id/index.php/siklus/article/view/298\%oAhttp://repositorio.u nan.edu.ni/2986/1/5624.pdf\%oAhttp://dx.doi.org/10.1016/j.jana.2015.10.005\%oAhttp://w ww.biomedcentral.com/1471-2458/12/58\%oAhttp://ovidsp.ovid.com/ovidweb.cgi?T=JS\&P

Ashadii, N. R., \& Suhaeb, S. (2020). Hubungan Pemanfaatan Google Classroom dan Kemandirian terhadap Hasil Belajar Mahasiswa PTIK pada Masa Pandemi. Media Elektronik, 17(2), 46-51.

Asmuni, A. (2020). Problematika Pembelajaran Daring di Masa Pandemi Covid-19 dan Solusi Pemecahannya. Jurnal Paedagogy, 7(4), 281. https://doi.org/10.33394/jp.v7i4.2941

Aydin, E., \& Erol, S. (2021). The Views of Turkish Language Teachers on Distance Education and Digital Literacy during Covid-19 Pandemic. International Journal of Education and Literacy Studies, 9(1), 6o. https://doi.org/10.7575/aiac.ijels.v.9n.1p.6o

Bagas Panca Pradana, D. (2017). Pengaruh Penerapan Tools Google Classroom pada Model Pembelajaran Project Based Learning terhadap Hasil Belajar Siswa. It-Edu, 2(o1).

Buchholz, B. A., DeHart, J., \& Moorman, G. (2020). Digital Citizenship During a Global Pandemic: 
Moving Beyond Digital Literacy. Journal of Adolescent and Adult Literacy, 64(1), 11-17. https://doi.org/10.1002/jaal.1076

Hidayah, \& dkk. (2020). Optimalisasi Pemanfaatan Aplikasi Google Classroom dan Google Form sebagai Penunjang Pembelajaran Daring di SMA Negeri 5 Cimahi. IComSE (Indonesian Community Service and Empowerment), 1(2), 55 - 60.

Ibda, H. (2018). Penguatan Literasi Baru Pada Guru Madrasah Ibtidaiyah Dalam Menjawab Tantangan Era Revolusi Industri 4.0. Journal of Research and Thought on Islamic Education (JRTIE), 1(1), 1-21. https://doi.org/10.2426o/jrtie.v1i1.1064

Indrianto, N., Latipah, N., Suharjo, Pratiwi, C. R. N. P., Kusumawati, H., Nuriyati, T., Handayani, E. S., Lehan, A. A. D., Suwantoro, Nadziroh, A., Noor, T. R., Yuliasti, R. N. K., Marzuki, A. G., Hamzah, Biduri, F. N., Astuti, D. P. J., Ulfa, M., Ma'arif, A. S., Sodik, A. J., ... Susanto, R. (2021). Waktunya Merdeka Belajar.

Kementerian Pendidikan dan Kebudayaan. (2017). Panduan Gerakan Literasi Nasional. Kemendikbud.

Kurnia, N., \& dkk. (2019). Literasi Digital Keluarga: Teori dan Praktik Pendampingan Orangtua terhadap Anak dalam Berinternet Penulis : Penerbit: Jogjakarta: Gadjah Mada University Press. Gadjah Mada University Press.

Lynch, M. (2020). E-Learning during a global pandemic. Asian Journal of Distance Education, 15(1), 2020. http://www.asianjde.org

Mu'minah, I. H., \& Gaffar, A. A. (2020). Optimalisasi penggunaan google classroom sebagai alternatif digitalisasi dalam pembelajaran jarak jauh (pjj). Al-Islah: Jurnal Pendidikan, 5, 2336.

Nahdi, D. S., \& Jatisunda, M. G. (2020). Analisis Literasi Digital Calon Guru Sd Dalam Pembelajaran Berbasis Virtual Classroom Di Masa Pandemi Covid-19. Jurnal Cakrawala Pendas, 6(2), 116123. https://doi.org/10.31949/jcp.v6i2.2133

Nirfayanti, N., \& Nurbaeti, N. (2019). Pengaruh Media Pembelajaran Google Classroom Dalam Pembelajaran Analisis Real Terhadap Motivasi Belajar Mahasiswa. Proximal Jurnal Penelitian Matematika Dan Pendidikan Matematika ISSN 26158132 (Cetak) ISSN 26157667 (Online), 2(1), 50-59. https://e-journal.my.id/proximal/article/view/211

Saragih, M., Nst, H. S., Harisma, R., \& Batubara, I. H. (2021). Digital Literation Models Development Based School Culture to Improve Students' Life Skill in the 21 st Century. 13(1).

Sudrajat, J. (2020). Kompetensi Guru Di Masa Pandemi Covid-19. Jurnal Riset Ekonomi Dan Bisnis, 13(2), 100. https://doi.org/10.26623/jreb.v13i2.2434

Sumiati, E., \& Wijonarko. (2020). Manfaat Literasi Digital Bagi Masyarakat Dan Sektor Pendidikan Pada Saat Pandemi Covid-19. Buletin Perpustakaan Universitas Islam Indonesia, 3(2), 65-80.

Suparjan, \& Maryadi. (2021). Google Classroom as a Distance Learning Media : Limitations and Overcoming Efforts. Al-Islah: Jurnal Pendidikan, 13(1).

Sutrisna, I. P. G. (2020). Gerakan Literasi Digital Pada Masa Pandemi Covid-19. Stilistika: Jurnal Pendidikan Bahasa Dan Seni, 8(2), 268-283. https://doi.org/10.5281/zenodo.3884420

Wulandari, I. A. G. (2021). Pemanfaatan Media Google Classroom Dalam Meningkatkan Mutu Pembelajaran Pada Masa Pandemi Covid-19 Di IHDN Denpasar. Jurnal Penjaminan Mutu, 7(4). http://ejournal.ihdn.ac.id/index.php/JPM/article/view/1825

Wulandari, M. A., Arga, H. S. P., Kelana, J. B., Altaftazani, D. H., \& Ruqoyyah, S. (2020). Analisis Pembelajaran "Daring” pada Guru Sekolah Dasar di Era Covid-19. Jurnal Ilmiah P2M STKIP Siliwangi P2M STKIP Siliwangi, 5(2), 1-6.

Yasni, A. (2020). Media Pembelajaran Daring pada Masa Covid-19 Online Learning Media during the Coronavirus Disease. Tarbiyatu Wa Ta'lim: Jurnal Pendidikan Agama Islam, 02, 49-56. 